\title{
INADEQUACY OF VITAMIN K ANTAGONIST USE IN PATIENTS WITH ATRIAL FIBRILLATION - OVERVIEW OF EVERYDAY CLINICAL PRACTICE AT THE MERKUR UNIVERSITY HOSPITAL IN ZAGREB, CROATIA
}

\author{
Mario Stipinović ${ }^{1,4}$,Tomislav Letilović1,3, Darko Počanić ${ }^{1}$, Bojana Aćamović Stipinoviće \\ Ena Kurtić ${ }^{1}$, Zrinka Sertić $\hat{c}^{3}$ and Helena Jerkićc ${ }^{1,3}$ \\ ${ }^{1}$ Division of Cardiology, Department of Medicine, Merkur University Hospital, Zagreb, Croatia; \\ ${ }^{2}$ Division of Hematology, Department of Medicine, Merkur University Hospital, Zagreb, Croatia; \\ ${ }^{3}$ University of Zagreb, School of Medicine, Zagreb, Croatia; \\ ${ }^{4}$ Josip Juraj Strossmayer University, Faculty of Medicine, Osijek, Croatia
}

\begin{abstract}
SUMMARY - Atrial fibrillation is the most common cardiac arrhythmia. It increases the risk of death and thromboembolic events. Vitamin K antagonists reduce these risks. Disadvantages of vita$\min \mathrm{K}$ antagonist therapy are narrow therapeutic range and interactions with drugs and food. In a single center prospective study, we enrolled 249 patients with atrial fibrillation over a 12 -month period. The aim of our study was to evaluate vitamin $\mathrm{K}$ antagonist use regarding the indication and adequate dose. Data on 249 consecutive patients with atrial fibrillation were collected before general availability of novel oral anticoagulants. Out of 249 patients, 160 (64.2\%) had indication for oral anticoagulant therapy. Only 81 (50.6\%) patients had vitamin K antagonist in therapy, 12 (14.8\%) of them in adequate dose. We also analyzed 129 patients aged over 75, of which $109(84.4 \%)$ had absolute indication for oral anticoagulant therapy. Only 34 (31.2\%) patients aged over 75 had been receiving vitamin $\mathrm{K}$ antagonist therapy and $6(17.6 \%)$ had the International Normalized Ratio values within the proposed therapeutic interval. We found a significantly higher rate of anticoagulant therapy introduction in patients under 75 years ( $\mathrm{p}=0.03)$, but there were no significant differences in the adequacy of anticoagulant therapy $(\mathrm{p}=0.89)$ between these two populations. Our results showed clear inadequacies of vitamin $\mathrm{K}$ antagonist treatment with a growing need for a wider use of novel oral anticoagulants.
\end{abstract} lants

Key words: Atrial fibrillation; Thromboembolism; Vitamin $K$ - antagonists and inhibitors; Anticoagu-

\section{Introduction}

Atrial fibrillation (AF) is the most common cardiac arrhythmia, primarily occurring in diseased, structurally altered heart ${ }^{1}$. Bearing in mind the progressive aging of the population, this arrhythmia is becoming a

Correspondence to: Helena Jerkic, $M D, P b D$, Division of Cardiology, Department of Medicine, Merkur University Hospital, Zajčeva 19, HR-10000 Zagreb, Croatia

E-mail: helenajerkic@yahoo.com

Received July 17, 2018, accepted September 24, 2018 significant problem, both from the medical and public health viewpoint, especially if left untreated or if treated inadequately. The incidence of AF in the general population is $1 \%-2 \%$, reaching up to $5 \%-15 \%$ in those over $80^{2,3}$. The likelihood of fatal outcome is twofold and the risk of thromboembolic events fivefold greater in AF patients ${ }^{4,5}$. The mentioned thromboembolic incidents carry a greater risk of both mortality and morbidity compared to patients without AF. The risk of complications does not depend on AF duration, its form or the presence of symptoms ${ }^{6}$. The risk of com- 
plications depends on the presence of comorbidity 6 The presence of comorbidities, most commonly referred to as CHADS2 score (congestive heart failure, hypertension, age $\geq 75$ years, diabetes mellitus, stroke [double weight]) or CHA2DS2 VASc score (congestive heart failure, hypertension, age $(>65=1$ point, $>75=2$ points), diabetes, previous stroke/transient ischemic attack (2 points); VASc (vascular disease [peripheral arterial disease, previous myocardial infarction, aortic atheroma], and sex category [female gender]) determines which patient has indication for use of anticoagulant therapy ${ }^{7}$.It has long been known that anticoagulant therapy significantly reduces the risk of death, as well as thromboembolic incidents ${ }^{8}$. Anticoagulant therapy or therapy with vitamin $\mathrm{K}$ antagonists (VKA) has been shown to be most effective in this indication, even in comparison with dual antiaggregation therapy ${ }^{9}$. Still, administration of VKA is anything but simple, considering the narrow therapeutic window demanding regular measurement of Prothrombin Time or International Normalized Ratio (PT/INR), as well as numerous interactions with food ingredients and other drugs. Many studies have shown that for this reason, VKA therapy is often not prescribed to patients in whom it is indicated and, when prescribed, is often inadequately dosed. In their study on $2587 \mathrm{pa}^{-}$ tients, McCormick et al. showed that $42 \%$ of AF patients were receiving warfarin, suggesting that this therapy continued to be used at low levels for stroke prevention; when warfarin was prescribed, the recommended therapeutic range of INR was maintained approximately half of the time ${ }^{10}$.

A recently published BALKAN AF study, which also included patients from Croatia, showed a relatively high overall use of oral anticoagulants (OAC); $73.6 \%$ of study patients were receiving $\mathrm{OAC}$, whereas VKA was administered to $60.9 \%$ and novel oral anticoagulants (NOAC) to $12.7 \%$ of study patients. When VKA was used, the quality of anticoagulation was poor, with less than one-third of patients having INR in the therapeutic range ${ }^{11}$.

According to these findings and the results of previous studies having shown NOACs to be a safe and effective alternative to warfarin, the rate of prescribing NOAC has been increasing in clinical practice. There is also a reduction in major bleeding events associated with NOACs, fewer interactions with drugs and foods, and no requirement for routine blood monitoring ${ }^{11}$.
The aim of our study was to assess the adequacy of VKA administration regarding the dose and indication in patients in our everyday clinical practice. It should be noted that our study was conducted before NOACs had become widely available.

\section{Patients and Methods}

This study retrospectively included 249 consecutive patients diagnosed with AF irrespective of its form and duration. The study was conducted at the Division of Cardiology, Merkur University Hospital, Zagreb, and the enrolment period was 12 months, from October 2010 to October 2011. The study was approved by the Hospital Ethics Committee and all patients provided their informed consent. Patients hospitalized for diagnostic or therapeutic procedures requiring discontinuation of OAC therapy were excluded from the study. All included patients were adult. The following data were collected: sex, age, anticoagulant therapy, antiaggregation therapy, PT/INR at arrival, and risk factors for development of thromboembolic events expressed by the CHADS2 score.

\section{Results}

The study included 249 patients, 104 (41.8\%) female and 145 (58.2\%) male, mean age 73.6 years. Baseline characteristics of the study population are shown in Table 1.

After being stratified by their CHADS2 score, 160 (64.2\%) patients had an absolute indication for administration of OAC therapy (CHADS $\geq 2), 76$ $(30.5 \%)$ had relative indication $(\mathrm{CHADS}=1)$, while only 13 (5.2\%) patients had no indication for OAC therapy (CHADS=0) (Fig. 1).

Table 1. Baseline characteristics of study patients

\begin{tabular}{|l|l|l|}
\hline Study patients, N=249 & $\mathrm{n}$ & $\%$ \\
\hline Male & 145 & \\
Female & 104 & 58.24 \\
Mean age (years) & 73.6 & 41.76 \\
Heart failure & 75 & 30.12 \\
Hypertension & 217 & 87.14 \\
Age $>75$ years & 129 & 51.80 \\
Diabetes mellitus & 61 & 24.49 \\
Previous stroke & 6 & 2.41 \\
\hline
\end{tabular}




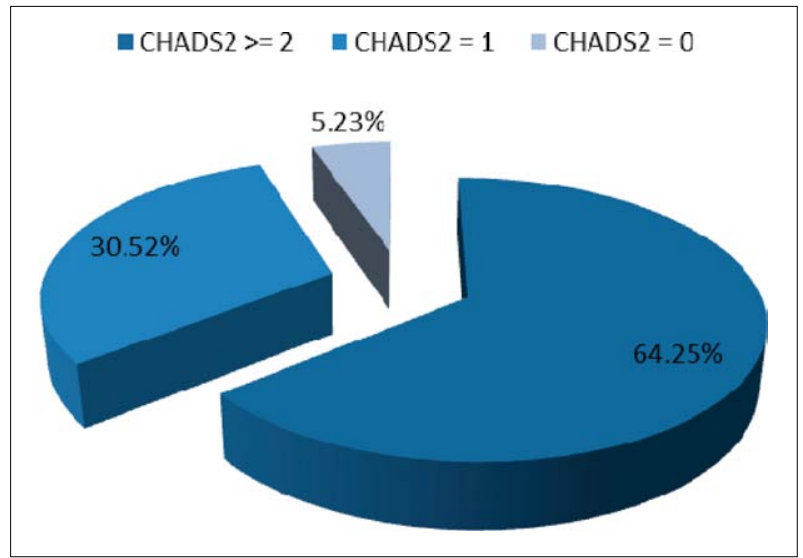

Fig. 1. Stroke risk profile of the study population.

Study population was also analyzed according to the CHADS2 stroke risk profile, and most of them had CHADS2 1 (30.5\%) or $2(30.9 \%)$ risk profile (Table 2).

Table 2. Patient stratification according to the CHADS2 stroke risk profile

\begin{tabular}{|l|l|l|}
\hline CHADS2 & $\mathrm{n}$ & $\%$ \\
\hline 0 & 13 & 5.22 \\
1 & 76 & 30.52 \\
2 & 77 & 30.92 \\
3 & 64 & 25.70 \\
4 & 10 & 4.02 \\
5 & 9 & 3.61 \\
\hline
\end{tabular}

CHADS2 = congestive heart failure, hypertension, age $\geq 75$ years, diabetes mellitus, stroke [double weight]

We further analyzed data on the adequacy of VKA administration regarding indication. Of the $160 \mathrm{pa}-$ tients with an absolute indication, only 81 (50.6\%) patients were on VKA at the time of admission. To assess the adequacy of VKA therapy regarding the dose, we analyzed the percentage of patients satisfactorily saturated with warfarin based on their INR values. Only $12(14.8 \%)$ of $81(50.6 \%)$ patients on OAC therapy on admission had INR values within the proposed therapeutic interval of 2-3 (median 2.30). The remaining $69(85.2 \%)$ patients had INR values beyond the therapeutic interval; $65(80.2 \%)$ patients had INR less than 2 (mean 1.38) and four (4.9\%) patients were VKA hypersaturated, with INR values $>3$ (mean 3.45) (Fig. 2).

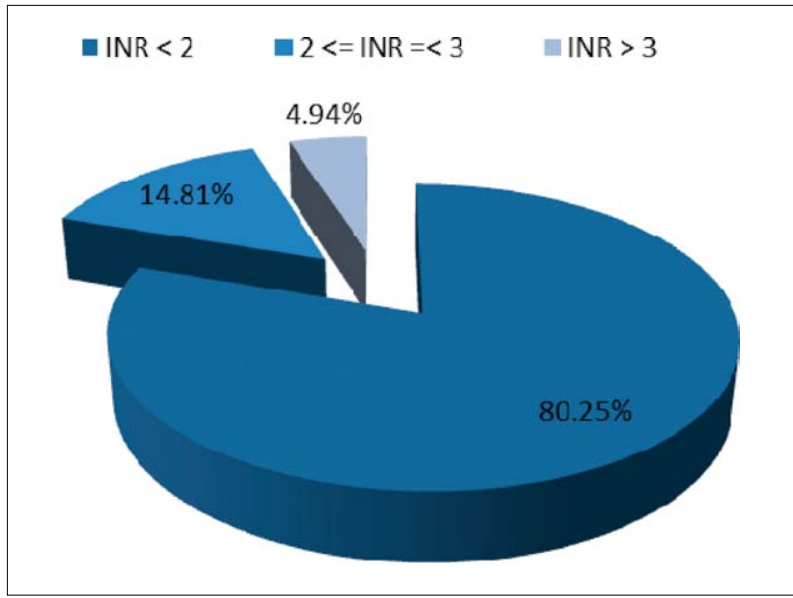

Fig. 2. Adequacy of vitamin $K$ antagonist therapy according to INR values.

Knowing that age is an independent risk factor for thromboembolic events, we analyzed the patients aged over 75 as a separate group. Their stroke risk profile is illustrated in Figure 3.

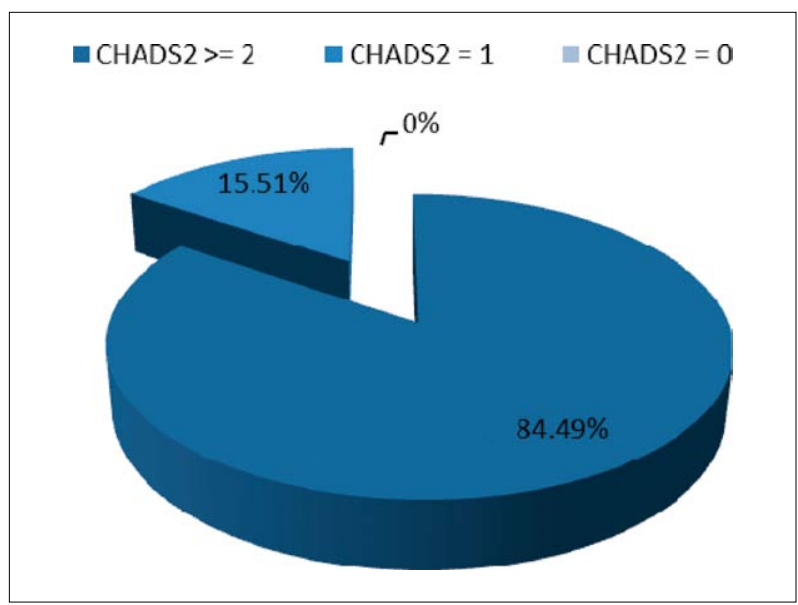

Fig. 3. Stroke risk profile in patients aged $>75$.

The aforementioned group included 129 (51.8\%) patients aged over 75, of which 109 (84.4\%) had an absolute indication for OAC therapy and only 34 (31.2\%) had been receiving VKA therapy. Only six (17.6\%) patients had INR values within the proposed therapeutic interval, whereas the remaining 28 (82.4\%) patients were inadequately saturated with VKA (Fig. 4).

We also found a significantly higher rate of anticoagulant therapy introduction in patients aged $<75$ as compared with those aged $>75(\mathrm{p}=0.03)$, but there were no significant differences in the adequacy of anti- 


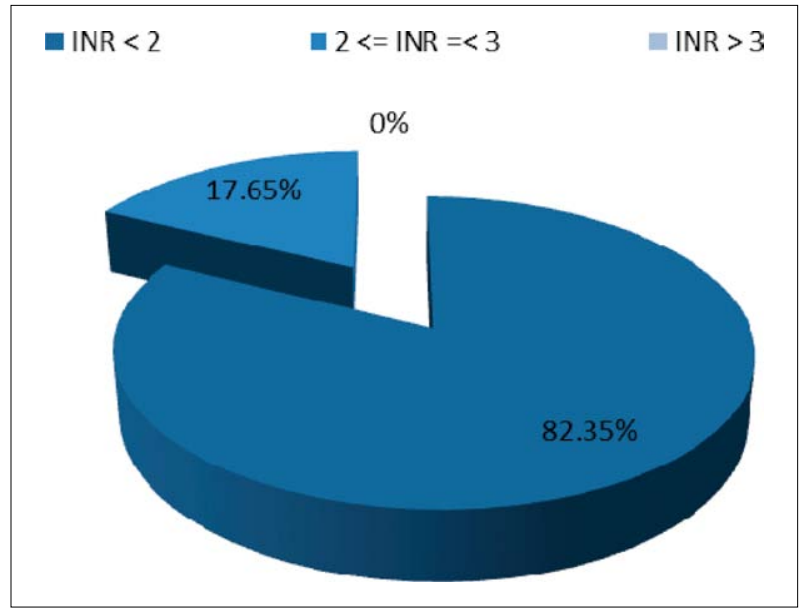

Fig. 4. Adequacy of vitamin Kantagonist therapy according to INR values in patients aged $>75$.

coagulant therapy $(\mathrm{p}=0.89)$ between these two populations. According to CHADS2 score risk profile groups we did not find significant differences in the percentages of patients with oral anticoagulant therapy and percentages of those with appropriately regulated INR.

\section{Discussion}

Although the efficacy of warfarin in preventing stroke and systemic embolism in AF patients was demonstrated in a number of randomized controlled trials, there remains considerable uncertainty regarding adequacy of warfarin administration and dosage ${ }^{12}$.

In our study, we found 160 (64.2\%) patients with indication for OAC and only $50.6 \%$ of them had VKA in therapy and $14.8 \%$ in adequate dose. Similar results have been reported in some previous studies. The study carried out by McCormick et al. in 2587 patients showed that warfarin was prescribed to $42 \%$ of AF patients and the therapeutic range of INR values was maintained only $51 \%$ of the time ${ }^{10}$.

A recently published BALKAN AF study showed some better results. This study enrolled 2712 patients from seven Balkan countries including Croatia; 73.6\% of study patients had been receiving OAC and $60.9 \%$ had VKA, while NOAC were administered to $12.7 \%$ of study patients. The BALKAN AF study included 159 Croats and $134(84.3 \%)$ of them had received OAC; 110 (69.2\%) and 24 (15.1\%) Croatian patients were administered VKA and NOAC, respectively. These results are newer, showing the situation in our country to be better than our results, as we collected them before NOAC general availability in Croatia, so it might be the reason for differences. The distribution of VKA therapies in Croatia was similar as in other Balkan countries, i.e. Albania, Montenegro, Romania and Serbia, but our results were better as compared with Bosnia and Herzegovina and Bulgaria. The authors of the BALKAN AF study showed that AF patients from Bosnia and Herzegovina and Bulgaria more often received only antiplatelet therapy, mainly aspirin, especially AF patients aged over $80^{11}$.

It is also known that VKA is highly effective in reducing the risk of stroke in older patients with AF. However, many studies found warfarin to be used continuously at low rates among elderly AF patients. Our results showed $33.9 \%$ of $A F$ patients aged $>75$ to have received VKA and 16\% of them had INR values within the proposed therapeutic interval. Failure to initiate VKA in elderly AF patients is related to a number of factors, including limitations of current therapies and the increased risk of major hemorrhage associated with advanced age. According to a recent study, about $33 \%$ of elderly patient hospitalizations due to adverse drug reactions, mostly hemorrhagic, are caused by warfarin, and another $13 \%$ by antiplatelet drugs, with a high risk for patients and costs for the society ${ }^{13}$. Fear from intracranial hemorrhage is a major factor in the widespread underuse of VKA in elderly people. One of four patients aged $>80$ also stops taking warfarin within the first year of initiation, predominantly because of these safety concerns ${ }^{14}$.

Interestingly, the 2008 Japanese AF guidelines do recommend an INR target of 1.6-2.6 in patients above 70 years ${ }^{15}$. However, the European and North American guidelines do not recommend lower INR levels in the elderly ${ }^{16}$. In addition, Hylek et al. demonstrated the INR above 2 to be associated not only with a lower risk of stroke, but also with a lower severity or risk of dying from stroke ${ }^{17}$.

According to our results and the results of these studies, NOAC should increase the use of antithrombotic therapy in the management of AF in older population. NOAC are easier to use and might offer similar or better levels of stroke prevention with a similar or reduced risk of bleeding than VKA.

Vitamin K antagonists were for a long time the only oral therapeutic option available for stroke prevention in AF patients. However, even after the intro- 
duction of NOAC to everyday clinical practice, VKA continue to be frequently prescribed, primarily for their lower price. There is also a population of AF patients in whom VKA is the only treatment option. According to the ESC guidelines for treatment of AF, VKA remain the only treatment option with proven efficacy in patients with $A F$ and mechanical valves or rheumatic mitral valve disease.

Oral anticoagulant therapy is recommended for men with CHA2DS2VASc score equal to or exceeding 1 , as well as in women with CHA2DS2VASc score equal to or exceeding $2^{16}$. The efficacy of VKA in lowering the relative risk of developing thromboembolic events, the absolute annual risk of thromboembolic stroke and the frequency of lethal outcomes has been proven in many studies ${ }^{18}$. There are, however, many disadvantages regarding administration of VKA, namely, their narrow therapeutic window, interactions with drugs and foods, the need for frequent and regular laboratory testing, and large inter-individual differences in the dose required ${ }^{19-21}$.

Many studies have shown that these disadvantages are responsible for the inadequate frequency of prescribing VKA in patients in whom they are indicated on the basis of valid guidelines and when VKA are prescribed, it is very often in insufficient dose $\mathrm{e}^{20,21}$.

In this study, we wanted to point out the lack of indications for initiation of oral anticoagulant therapy, as well as the issue of maintaining optimal INR in the therapeutic range of $2-3$. A total of $85.2 \%$ of patients who were on OAC therapy at the time of admission had INR outside the therapeutic range. Especially concerning was the fact that as little as $17.6 \%$ of patients in the $>75$ age group had INR within the prescribed range, considering that age is the most important predictive factor for development of stroke and major bleeding events in AF patients ${ }^{22,23}$. This is why age over 75 was included in the CHA2DS2VASc score as an independent factor worthy 2 points, which makes it a reason enough in itself for initiation of OAC therapy. NOAC are a suitable alternative to warfarin for stroke prevention in AF patients and their use is increasing in everyday clinical practice. Studies such as ARISTOTLE, RE-LY, ENGAGE-AF-TIMI 48 and ROCKET-AF showed a significantly better efficacy compared to warfarin with equal or less risk of bleeding ${ }^{24-27}$. For this improved efficacy and equal or lower bleeding risk, we expect an increase in the use of NOAC resulting in better patient compliance to therapy and better protection from thromboembolic events, whic is especially important in patients aged $>75$.

The potential disadvantages of our study included the fact that we used CHADS2 score instead of the currently recommended CHA2DS2VASc score to assess the indication for therapy. It is known that the CHA2DS2VASc score is significantly more sensitive in recognizing high-risk patients. We assume that by using the CHA2DS2VASc score, the number of patients requiring anticoagulation therapy would be even higher, which would make our results yielding an even worse ratio of VKA use according to indication.

However, at the time when this study was performed, the CHADS2 score was still valid and as such was calculated in all patients at admission. The final statistical analysis of the data collected was also based on the CHADS2 score. The attempt of subsequent insertion of data required to calculate the CHA2DS2VASc score in a short pilot project was found to be unsuccessful since the required clinical data were not routinely recorded at the time. Considering that even the results based on the CHADS2 score showed inadequate use of VKA, we deem them sufficient to conclude that VKA therapy was inadequate in our patients. It should be emphasized that the number of patients included in this study was relatively small. Considering better availability of NOAC, a greater number of patients will require data collection over a longer period of time, as well as a greater number of institutions involved in this potential research project.

\section{Conclusion}

In conclusion, our study showed the use of VKA in Croatia to be probably inadequate. Such results should direct us towards improving screening of patients in need of anticoagulant therapy, as well as better control of therapy administration. These results probably support the need for a more frequent use of NOAC, which would make at least some of the above mentioned VKA therapy disadvantages less pronounced.

\section{References}

1. Frustaci A, Chimenti C, Bellocci F, Morgante E, Russo MA, Maseri A. Histological substrate of atrial biopsies in patients with lone atrial fibrillation. Circulation. 1997;96:1180-4, https: //doi.org/10.1161/01.CIR.96.4.1180. 
2. Stewart S, Hart CL, Hole DJ, McMurray JJ. Population prevalence, incidence, and predictors of atrial fibrillation in the Renfrew/Paisley study. Heart. 2001;86:516-21, http://dx.doi. org/10.1136/heart.86.5.516.

3. Go AS, Hylek EM, Phillips KA, Chang Y, Henault LE, Selby JV, Singer DE. Prevalence of diagnosed atrial fibrillation in adults: national implications for rhythm management and stroke prevention: the AnTicoagulation and Risk Factors in Atrial Fibrillation (ATRIA) Study. JAMA. 2001;285:2370-5, http://doi:10.1001/jama.285.18.2370.

4. Miyasaka Y, Barnes ME, Gersh BJ, Cha SS, Bailey KR, Abhayaratna WP, Seward JB, Tsang TS. Secular trends in incidence of atrial fibrillation in Olmsted County, Minnesota, 1980 to 2000, and implications on the projections for future prevalence. Circulation. 2006;114:119-25, https://doi.org/ 10.1161/CIRCULATIONAHA.105.595140.

5. Heeringa J, van der Kuip DA, Hofman A, Kors JA, van Herpen G, Stricker BH, Stijnen T, Lip GY, Witteman JC. Prevalence, incidence and lifetime risk of atrial fibrillation: the Rotterdam study. Eur Heart J. 2006;27:949-53, https://doi.org/10.1093/ eurheartj/ehi825.

6. Friberg L, Hammar N, Rosenqvist M. Stroke in paroxysmal atrial fibrillation: report from the Stockholm Cohort of Atrial Fibrillation. Eur Heart J. 2010;31: 967-75, https://doi.org/ 10.1093/eurheartj/ehn599.

7. Gage BF, Waterman AD, Shannon W, Boechler M, Rich MW, Radford MJ. Validation of clinical classification schemes for predicting stroke: results from the National Registry of Atrial Fibrillation. JAMA. 2001;285:2864-70, https://doi. org/10.1001/jama.285.22.2864.

8. Hart RG, Pearce LA, Aguilar MI. Meta-analysis: antithrombotic therapy to prevent stroke in patients who have nonvalvular atrial fibrillation. Ann Intern Med. 2007;146:857-67, https://doi.org/10.7326/0003-4819-146-12-20070619000007.

9. Connolly S, Pogue J, Hart R, Pfeffer M, Hohnloser S, Chrolavicius S, Yusuf S. Clopidogrel plus aspirin versus oral anticoagulation for atrial fibrillation in the Atrial fibrillation Clopidogrel Trial with Irbesartan for prevention of Vascular Events (ACTIVE W): a randomised controlled trial. Lancet. 2006; 367:1903-12, https://doi.org/10.1016/s0140-6736(06)68845-4.

10. McCormick D1, Gurwitz JH, Goldberg RJ, Becker R, Tate JP, Elwell A, Radford MJ. Prevalence and quality of warfarin use for patients with atrial fibrillation in the long-term care setting. Arch Intern Med. 2001 Nov 12;161(20):2458-63, https://doi. org/10.1001/archinte.161.20.2458.

11. Potpara TS, Dan GA, Trendafilova E, Goda A, Kusljugic Z, Manola S, Music L, Musetescu R, Badila E, Mitic G, Paparisto V, Dimitrova ES, Polovina MM, Petranov SL, Djergo H, Loncar D, Bijedic A, Brusich S, Lip GY; Stroke prevention in atrial fibrillation and 'real world' adherence to guidelines in the Balkan Region: The BALKAN-AF Survey. Sci Rep 6, 20432 (2016) https://doi:10.1038/srep20432.

12. Lakshminarayan K, Solid CA, Collins AJ, Anderson DC, Herzog CA. Atrial fibrillation and stroke in the general medicare population: a 10-year perspective (1992 to 2002). Stroke. 2006;37(8):1969-74, https://doi.org/10.1161/01.str.00002306 07.07928.17.

13. Pellizzari L. Warfarin and elderly patients: a challenging combination. Focus Farmacovigilanza. 2012;73(11):6.

14. Hylek EM, Evans-Molina C, Shea C, Henault LE, Regan S. Major hemorrhage and tolerability of warfarin in the first year of therapy among elderly patients with atrial fibrillation. Circulation. 2007;115(21):2689-96, https://doi.org/10.1161/circulationaha.106.653048.

15. JCS Joint Working Group. Guidelines for pharmacotherapy of atrial fibrillation (JCS 2008): digest version. Circ J. 2010; 74(11):2479-500, https://doi.org/10.1253/circj.cj-88-0001.

16. Kirchhof P, Benussi S, Kotecha D, Ahlsson A, Atar D, Casadei B, Castella M, Diener CH, Heidbuchel H, Hendriks J, Hindricks G, Manolis AS, Oldgren J, Popescu BA, Schotten U, Van Putte B, and Vardas P. 2016 ESC Guidelines for the management of atrial fibrillation developed in collaboration with EACTS. Eur Heart J. 2016;37:2893-962, https://doi.org/ 10.5603/kp.2016.0172.

17. Hylek EM, Go AS, Chang Y, Jensvold NG, Henault LE, Selby JV, Singer D. Effect of intensity of oral anticoagulation on stroke severity and mortality in atrial fibrillation. N Engl J Med. 2003;349(11):1019-26, https://doi.org/10.1056/nejmoa022913.

18. Connolly SJ, Ezekowitz MD, Yusuf S, Eikelboom J, Oldgren J, Parekh A, Pogue J, Reilly PA, Themeles E, Varrone J, Wang S, Alings M, Xavier D, Zhu J, Diaz R, Lewis BS, Darius H, Diener H-Ch, Joyner CD, Wallentin L; RE-LY Steering Committee and Investigators. Dabigatran versus warfarin in patients with atrial fibrillation. N Engl J Med. 2009;361:1139-51, https://doi.org/10.1056/nejmoa0905561.

19. Birman-Deych E, Radford MJ, Nilasena DS, Gage BF. Use and effectiveness of warfarin in Medicare beneficiaries with atrial fibrillation. Stroke. 2006;37:1070-4, https://doi.org/ 10.1161/01.str.0000208294.46968.a4.

20. Hylek EM, Evans-Molina C, Shea C, Henault LE, Regan S. Major hemorrhage and tolerability of warfarin in the first year of therapy among elderly patients with atrial fibrillation. Circulation. 2007;115:2689-96, https://doi.org/10.1161/circulationaha.106.653048.

21. Bozina N. The pharmacogenetics of warfarin in clinical practice. Biochem Med. 2010;20(1):33-44, https://doi.org/ 10.11613/bm.2010.005.

22. Friberg L, Rosenqvist M, Lip GY. Evaluation of risk stratification schemes for ischaemic stroke and bleeding in $182678 \mathrm{pa}^{-}$ tients with atrial fibrillation: the Swedish Atrial Fibrillation cohort study. Eur Heart J. 2012;33:1500-10, https://doi. org/10.1093/eurheartj/ehr488.

23. Hijazi Z, Oldgren J, Lindback J, Alexander JH, Connolly SJ, Eikelboom JW, Ezekowitz MD, Held C, Hylek EM, Lopes RD, Siegbahn A, Yusuf S, Granger CB, Wallentin L, ARISTOTLE and RE-LY Investigators. The novel biomarker-based $\mathrm{ABC}$ (age, biomarkers, clinical history)-bleeding risk score 
for patients with atrial fibrillation: a derivation and validation study. Lancet. 2016;387:2302-11, https://doi.org/10.1016/ s0140-6736(16)00741-8.

24. Granger CB, Alexander JH, McMurray JJ, Lopes RD, Hylek EM, Hanna M, Al-Khalidi HR, Ansell J, Atar D, Avezum A, Bahit MC, Diaz R, Easton JD, Ezekowitz JA, Flaker G, Garcia D, Geraldes M, Gersh BJ, Golitsyn S, Goto S, Hermosillo AG, Hohnloser SH, Horowitz J, Mohan P, Jansky P, Lewis BS, Lopez-Sendon JL, Pais P, Parkhomenko A, Verheugt FW, Zhu J, Wallentin L, AR- ISTOTLE Committees and Investigators. Apixaban versus warfarin in patients with atrial fibrillation. $\mathrm{N}$ Engl J Med. 2011;365:981-92, https://doi.org/10.1056/nejmoa1107039.

25. Connolly SJ, Ezekowitz MD, Yusuf S, Eikelboom J, Oldgren J, Parekh A, Pogue J, Reilly PA, Themeles E, Varrone J, Wang S, Alings M, Xavier D, Zhu J, Diaz R, Lewis BS, Darius H, Diener HC, Joyner CD, Wallentin L, RE-LY Steering Commit- tee and Investigators. Dabigatran versus warfarin in patients with atrial fibrillation. N Eng1 J Med. 2009;361:1139-51, https://doi.org/10.1056/nejmoa0905561.

26. Giugliano RP, Ruff CT, Braunwald E, Murphy SA, Wiviott SD, Halperin JL, Waldo AL, Ezekowitz MD, Weitz JI, Spinar J, Ruzyllo W, Ruda M, Koretsune Y, Betcher J, Shi M, Grip LT, Patel SP, Patel I, Hanyok JJ, Mercuri M, Antman EM, Investigators EA-T. Edoxaban versus warfarin in patients with atrial fibrillation. N Engl J Med. 2013;369:2093-104, https://doi. org/10.1056/nejmoa1310907.

27. Patel MR, Mahaffey KW, Garg J, Pan G, Singer DE, Hacke W, Breithardt G, Halperin JL, Hankey GJ, Piccini JP, Becker RC, Nessel CC, Paolini JF, Berkowitz SD, Fox KA, Califf RM, ROCKET AF Investigators. Rivaroxaban versus warfarin in nonvalvular atrial fibrillation. N Engl J Med. 2011;365:883-91, https://doi.org/10.1056/nejmoa1009638.

Sažetak

\section{NEDOSTATNA PRIMJENA ANTAGONISTA VITAMINA K U BOLESNIKA S ATRIJSKOM FIBRILACIJOM - PRIKAZ REZULTATA IZ KLINIČKE PRAKSE U KLINIČKOJ BOLNICI “MERKUR”, ZAGREB}

\section{Stipinović, T. Letilović, D. Pǒ́anić, B. Aćamović Stipinović, E. Kurtic, Z. Sertić i H. Jerkić}

Atrijska fibrilacija je najučestalija aritmija koja povećava rizik smrti i tromboembolijskih incidenata. Antagonisti vitamina K smanjuju taj rizik. Problem terapije s antagonistima vitamina $\mathrm{K}$ je uska terapijska širina i brojne interakcije s lijekovima $\mathrm{i}$ hranom. Cilj ovoga istraživanja bio je utvrditi dostatnost primjene antagonista vitamina $\mathrm{K}$ s obzirom na indikaciju i dozu. Prikupljeni su podaci 249 bolesnika s atrijskom fibrilacijom hospitaliziranih u Kliničkoj bolnici "Merkur" u razdoblju od 12 mjeseci i to prije šire dostupnosti novijih oralnih antiokoagulansa. Od svih bolesnika, $160(64,2 \%)$ ih je imalo indikaciju za primjenu oralne antikoagulantne terapije, a tek je njih 81 (50,6\%) imalo antagonist vitamina $\mathrm{K}$ u terapiji. Samo $12(14,8 \%)$ bolesnika je uzimalo antagonist vitamina K u dostatnoj dozi, a 129 (51,8\%) ih je bilo iznad 75 godina starosti. Njih 109 $(84,4 \%)$ je imalo indikaciju za oralnu antikoagulantnu terapiju, a samo $34(31,2 \%)$ ih je uzimalo antagonist vitamina $\mathrm{K}$, od kojih je $6(17,6 \%)$ imalo INR u terapijskim vrijednostima. Statistička analiza podataka pokazala je da su bolesnici mlađi od 75 godina češće uzimali indiciranu oralnu antikoagulantnu terapiju u odnosu na bolesnike starije od 75 godina ( $\mathrm{p}=0,03)$, dok nije bilo statistički značajne razlike u dostatnoj primjeni antikoagulantne terapije između ovih dviju populacija $(\mathrm{p}=0,89)$. Naši rezultati jasno pokazuju nedostatnosti primjene antagonista vitamina $\mathrm{K}$ kao i potrebu bržeg prijelaza prema terapiji novijim oralnim antikoagulansima.

Ključne riječi: Atrijska fibrilacija; Tromboembolija; Vitamin K-antagonisti i inhibitori; Antikoagulansi 